DOI: $10.29303 / \mathrm{jrpb} . v 9 \mathrm{i} 2.293$

ISSN 2301-8119, e-ISSN 2443-1354

Tersedia online di http://jrpb.unram.ac.id/

\title{
SINTESIS ZEOLIT DARI EKSTRAK SEKAM PADI DAN KALENG BEKAS SEBAGAI ADSORBEN PENURUNAN KESADAHAN AIR
}

\author{
Zeolite Synthesis from Rice Husk Extract and Used Cans \\ as Adsorbent to Reduce Water Hardness
}

\section{Herawati Oktavianty*), Sunardi, Rejang Musi Agastya Arianda Saputra Wardani}

Program Studi Teknologi Hasil Pertanian, Institut Pertanian STIPER Yogyakarta J1. Nangka II, Maguwoharjo, Sleman, Yogyakarta, Indonesia

\author{
Email $^{*}$ : hera.oktavianty@gmail.com
}

Diterima: Juli 2021

Disetujui: September 2021

\begin{abstract}
Rice husk and used cans are waste that are commonly encountered and have not been maximized in use. The aims of this study are to utilize waste rice husks and used cans to produce zeolite as an adsorbent for reducing water hardness (metal ion $\mathrm{Ca}^{2+}$ and $\mathrm{Mg}^{2+}$ ). This study used a complete block design with two factors, namely the mass factor of used cans $(1 \mathrm{~g} ; 2 \mathrm{~g}$; $3 \mathrm{~g})$ and the mass factor of rice husks extract $(60 \mathrm{~g} ; 80 \mathrm{~g} ; 100 \mathrm{~g})$. This experiment consisted of two stages, namely the synthesis of zeolite and the use of zeolite to reduce water hardness. XRD analysis were performed for zeolite and AAS analysis for water hardness. The experimental results showed that the adsorption of metal ions $\mathrm{Ca}^{2+}$ and $\mathrm{Mg}^{2+}$ was optimal in zeolite conditions with a mass composition of $2 \mathrm{~g}$ of used can and $80 \mathrm{~g}$ of rice husk extract, which were $94.48 \%$ and $89.26 \%$, respectively.
\end{abstract}

Keywords: adsorbent; rice husk extract; used cans; water hardness; zeolite

\begin{abstract}
ABSTRAK
Sekam padi dan kaleng bekas merupakan limbah yang banyak ditemui dan belum dimaksimalkan pemanfaatannya. Tujuan dari penelitian ini adalah untuk memanfaatkan limbah sekam padi dan kaleng bekas menjadi zeolit sebagai adsorben penurunan kesadahan air (ion $\operatorname{logam} \mathrm{Ca}^{2+}$ dan $\mathrm{Mg}^{2+}$ ). Penelitian ini menggunakan rancangan blok lengkap dengan dua faktor, yaitu faktor massa kaleng bekas ( 1 gr; 2 gr; 3 gr) dan faktor massa ekstrak sekam padi (60 gr; 80 gr; 100 gr). Percobaan ini terdiri atas dua tahap, yaitu pembuatan zeolit dan penggunaan zeolit untuk penurunan kesadahan air. Analisis XRD dilakukan untuk zeolit dan analisis AAS untuk kesadahan air. Dari hasil percobaan didapatkan penyerapan ion logam $\mathrm{Ca}^{2+}$ dan $\mathrm{Mg}^{2+}$ optimal pada kondisi zeolit dengan komposisi massa kaleng bekas 2 gr dan massa ekstrak sekam padi 80 gr, yaitu sebesar $94,48 \%$ dan $89,26 \%$.
\end{abstract}

Kata kunci: adsorben; ekstrak sekam padi; kaleng bekas; kesadahan air; zeolit 


\section{PENDAHULUAN}

\section{Latar Belakang}

Industri kaleng mulai meluas di Indonesia seiring dengan penggunaanya terhadap minuman ringan, dan makanan kaleng. Meningkatnya penggunaan kaleng sebagai wadah makanan atau minuman memberikan masalah lingkungan yang menjadi perhatian bersama. Kaleng-kaleng tersebut menjadi salah satu bahan bahan pencemar yang mengganggu lingkungan. Kemampuan kaleng aluminium bekas untuk dapat didaur ulang menjadi kaleng kembali adalah mencapai 95\% (Adans, et al., 2016). Kaleng aluminium bekas juga dapat dimanfaatkan sebagai bahan tambahan pembuatan tawas sintetis sebagai koagulan air, dimana kaleng bekas sebagai sumber $\mathrm{Al}$ di-treatment dahulu untuk kemudian dilarutkan dengan larutan $\mathrm{H}_{2} \mathrm{SO}_{4}$ untuk menghasilkan $\mathrm{Al}_{2}\left(\mathrm{SO}_{4}\right) 3$ atau tawas sintesis dihasilkan kadar kesadahan total kalsium karbonat maksimum sebesar $2.640 \mathrm{mg} / \mathrm{L}$ dan kadar sulfat maksimum adalah 72,7 mg/L (Hasmawati, 2017; Arviani, 2019).

$$
\text { Data Badan Pusat Statistik }
$$

Kementerian Pertanian Indonesia menunjukkan produktivitas padi rerata di tahun 2018 mencapai 53,54 Ku/Ha. Sekam padi merupakan limbah dari pertanian yang dapat mencapai $20 \%$ dari total limbah, dimana silika merupakan unsur utama dengan kadar 93-99\% dari total $15-20 \%$ komponen penyusunnya (Agung, et al., 2013).

Abu sekam padi dapat digunakan sebagai bahan baku pembuatan material zeolit dengan menggunakan metode hidrotermal. Zeolit adalah material berpori, yang memiliki kemampuan adsorpsi (adsorption), pertukaran ion (ion exchanger), maupun katalisator (catalyst) (Suardana, 2008). Selain itu, zeolit adalah material silikat kristal yang memiliki struktur yang teratur dengan porositas yang tinggi. Adapun rumus umum zeolit adalah $\mathrm{Mx} / \mathrm{n}\left(\mathrm{AlO}_{2}\right) \mathrm{x}\left(\mathrm{SiO}_{2}\right) \mathrm{y} . \mathrm{z} \cdot \mathrm{H}_{2} \mathrm{O} \quad(\mathrm{M}$ : kation yang bervalensi di luar kerangka yang dapat dipertukarkan) (Silalahi, et al., 2011). Untuk menghasilkan zeolit dengan karakteristik penyerap yang baik, zeolit dapat diaktivasi dengan menggunakan asam. Pada penambahan asam kuat $(\mathrm{HCl})$ sebagai aktivator, dihasilkan silika dengan kemurnian lebih dari 90\% (Daffalla, et al., 2012).

Arang sekam padi mampu menyerap ion logam Cd sebesar 70,42\% dan ion logam $\mathrm{Cr}$ sebesar $71,55 \%$ pada air limbah multikomponen (Nurhasni, et al., 2010). Penelitian terdahulu melakukan sintesis zeolit dari abu sekam padi yang menghasilkan zeolit $\mathrm{A}$ atau zeolit dengan kadar Si rendah, dimana rasio Si/Al hanya mendekati 1 (satu) saja (Era, et al., 2016). Pada penelitian ini diharapkan, arang sekam padi dapat menyerap logam berat lainnya dengan cara mengkonversi arang sekam padi dengan kaleng bekas menjadi zeolit sebagai adsorben.

\section{Tujuan}

Penelitian ini bertujuan untuk menghasilkan zeolit dengan rasio Si/Al yang tinggi dimana zeolit dibuat dengan memanfaatkan limbah pertanian, yaitu sekam padi sebagai sumber silika ( $\mathrm{Si}$ ) dan kaleng bekas sebagai sumber aluminium (Al), dengan variabel percobaan massa ekstrak sekam padi dan massa kaleng bekas. Setelah zeolit dihasilkan, dilakukan aplikasi pada penurunan kesadahan air.

\section{METODE PENELITIAN}

\footnotetext{
Alat dan Bahan

Alat-alat yang digunakan antara lain hot plate, magnetic stirrer, timbangan analitik, pompa vakum, furnace, oven, Atomic Absorption Spectrophotometry (AAS), X-Ray Diffraction (XRD), Brunauer Emmet Teller (BET) Surface Area Analysis serta peralatan gelasnya. Adapun bahanbahan yang diperlukan antara lain TPAOH, $\mathrm{NaOH}, \mathrm{HNO}_{3}$, sekam padi, kaleng bekas, akuades dan sampel air sumur.
} 


\section{Metode}

Metode penelitian ini dilakukan dengan menggunakan metode Response Surface Methodology (RSM). Desain percobaan menggunakan Central Composite Design (CCD) dengan total percobaan 10 kali, dengan 2 variabel bebas, yaitu massa ekstrak sekam padi dan massa kaleng bekas. Optimasi dilakukan dengan menggunakan bantuan Software Design Expert 12.

\section{Preparasi Kaleng Bekas}

Preparasi kaleng aluminium bekas dilakukan dengan cara mengamplas kaleng aluminium bekas, lalu cuci dengan air sabun hingga bersih dari pengotor, kemudian dikeringkan dan dikecilkan ukurannya hingga $0,5 \mathrm{~cm}$.

\section{Preparasi Sekam Padi}

Sekam padi dicuci dengan air panas, disaring lalu buang pengotornya, sedangkan sekam padi yang tenggelam dipisahkan, lalu direndam dengan larutan $\mathrm{HNO}_{3} \quad 10 \%$ selama 12 jam. Kemudian dilakukan pembilasan dengan air bersih, dilanjutkan dengan pengeringan. Sebanyak 200 gr sekam padi dimasukkan ke dalam $2000 \mathrm{~mL}$ larutan $\mathrm{NaOH} 1,5 \%$, dididihkan selama 30 menit. Hasil ekstraksi didinginkan pada suhu kamar, kemudian didiamkan selama 12 jam lalu disaring sehingga diperoleh filtrat yang mengandung silika (sol silika). Selanjutnya ditambahkan larutan $\mathrm{HNO}_{3} \quad 10 \%$ secara bertahap hingga terbentuk sol silika. $\mathrm{pH}$ diukur hingga netral $(\mathrm{pH}=7)$ dengan menggunakan indikator universal. Lalu gel silika yang terbentuk pada suhu kamar didiamkan dan dicuci dengan air panas sambil disaring menggunakan saringan 200 mesh hingga bersih dan putih. Hasil silika dikeringkan dengan menggunakan oven pada suhu $80^{\circ} \mathrm{C}$ hingga kering lalu dihaluskan (Simanjuntak \& Sembiring, 2016).

\section{Sintesis Zeolit}

Tahap pertama, yaitu sebanyak 11,2 gr $\mathrm{NaOH}$ dilarutkan ke dalam $450 \mathrm{~mL}$ akuades, lalu ditambahkan 2,5 mL larutan TPAOH dan diaduk perlahan hingga homogen. Larutan prekursor dibagi menjadi dua, yaitu $250 \mathrm{~mL}$ dan $200 \mathrm{~mL}$ yang digunakan untuk melarutkan silika. Di tahap kedua dilakukan pembuatan larutan alumina dengan cara potongan kaleng aluminium dimasukkan ke dalam $200 \mathrm{~mL}$ larutan prekursor secara perlahan, lalu diaduk hingga homogen. Tahap ketiga, yaitu pembuatan larutan silika, ekstrak sekam padi dimasukkan ke dalam $250 \mathrm{~mL}$ larutan prekursor hingga homogen, kemudian dicampur dengan larutan aluminium hingga homogen (Yang, et al., 2017).

Campuran larutan kemudian dimasukkan ke dalam botol polipropilen dan dilanjutkan dengan proses kristalisasi dengan menggunakan oven pada suhu $100^{\circ} \mathrm{C}$ selama 48 jam. Hasil gel zeolit selanjutnya dicuci dengan akuades lalu dikeringkan pada suhu $80{ }^{\circ} \mathrm{C}$. Akan didapatkan padatan kristal sebagai produk zeolite, lalu dihaluskan dan disaring dengan menggunakan saringan 200 mesh (Yang et al., 2017). Selanjutnya zeolit dikalsinasi menggunakan furnace pada suhu $550^{\circ} \mathrm{C}$ selama 5 (Yang, et al., 2017).

\section{Penyerapan Kesadahan Air}

Sebanyak $10 \mathrm{~mL} \mathrm{HNO}_{3}$ pekat/liter ditambahkan pada sampel air sumur, lalu diukur kadar ion logam $\mathrm{Mg}^{2+}(38,226 \mathrm{mg} / \mathrm{L})$ dan $\mathrm{Ca}^{2+} \quad(215,531 \mathrm{mg} / \mathrm{L})$ dengan menggunakan AAS, sebelum dan setelah adsorpsi. Zeolit sintetis ditimbang sebanyak 0,125 gr lalu dimasukkan ke dalam $25 \mathrm{~mL}$ sampel air sumur. Kemudian diaduk dengan shaker selama 60 menit lalu campuran larutan didiamkan selama 45 menit, untuk selanjutnya diukur kandungan ion logam $\mathrm{Ca}^{2+}$ dan $\mathrm{Mg}^{2+}$ pada filtrat dengan menggunakan AAS (Kristiyani, et al., 2012).

\section{HASIL DAN PEMBAHASAN}

Hasil uji AAS untuk penyerapan ion logam $\mathrm{Ca} 2+$ dan $\mathrm{Mg} 2+$ ditunjukkan pada Tabel 1. 
Tabel 1. Hasil uji AAS untuk penyerapan ion logam $\mathrm{Ca}^{2+}$ dan $\mathrm{Mg}^{2+}$

\begin{tabular}{ccccc}
\hline Run & $\begin{array}{c}\text { Massa } \\
\text { ekstrak } \\
\text { sekam } \\
\text { padi (gr) }\end{array}$ & $\begin{array}{c}\text { Massa } \\
\text { kaleng } \\
\text { bekas } \\
(\mathrm{gr})\end{array}$ & $\begin{array}{c}\mathrm{Ca}^{2+} \\
(\%)\end{array}$ & $\begin{array}{c}\mathrm{Mg}^{2+} \\
(\%)\end{array}$ \\
\hline 1 & 60 & 1 & 53,89 & 43,13 \\
2 & 100 & 1 & 79,29 & 64,21 \\
3 & 60 & 3 & 52,43 & 42,27 \\
4 & 100 & 3 & 78,38 & 63,18 \\
5 & 51,72 & 2 & 49,11 & 41,32 \\
6 & 108,28 & 2 & 72,54 & 53,76 \\
7 & 80 & 0,59 & 80,13 & 70,13 \\
8 & 80 & 3,41 & 89,11 & 72,17 \\
9 & 80 & 2 & 94,49 & 89,27 \\
10 & 80 & 2 & 94,47 & 89,25 \\
\hline
\end{tabular}

\section{Penyerapan ion logam $\mathrm{Ca}^{2+}$}

Hubungan antara pengaruh massa ekstrak sekam padi dengan massa kaleng bekas ditunjukkan pada Gambar 1 dan Gambar 2. Semakin banyak jumlah ekstrak sekam padi yang digunakan maka akan meningkatkan rasio $\mathrm{Si} / \mathrm{Al}$ pada zeolit, dibandingkan banyaknya jumlah kaleng bekas yang ditambahkan. Hal ini didukung oleh penelitian sebelumnya (Nurhasni, et al., 2010) yang menunjukkan semakin besar massa sekam padi yang digunakan, maka efisiensi penyerapan terhadap ion logam semakin besar (efisiensi penyerapan hingga $70,78 \%$ ). Meningkatnya rasio $\mathrm{Si} / \mathrm{Al}$ pada zeolit akan meningkatkan penyerapan ion logam $\mathrm{Ca}^{2+}$. Penyerapan ion logam $\mathrm{Ca}^{2+}$ mencapai optimal pada penggunaan $80 \mathrm{gr}$ ekstrak sekam padi dan mengalami penurunan ketika penggunaan $100 \mathrm{gr}$ ekstrak sekam padi. Hal ini terjadi karena semakin banyak adsorban yang terserap pada permukaan partikel zeolit dengan bertambahnya sisi aktif pada partikel zeolit yang menyerap ion logam.

\section{Penyerapan ion logam $\mathrm{Mg}^{2+}$}

Gambar 3 dan Gambar 4 menunjukkan interaksi antara pengaruh massa ekstrak sekam padi dengan massa kaleng, dimana semakin banyak jumlah ekstrak sekam padi yang digunakan maka akan meningkatkan jumlah partikel dan luas permukaan zeolit. Hal ini menyebabkan jumlah lokasi pengikatan ion logam juga bertambah sehingga efisiensi penyerapan juga meningkat (efisiensi penyerapan hingga 70,78\%) (Nurhasni, et al., 2010). Namun, penyerapan ion logam $\mathrm{Mg}^{2+}$ mencapai optimal ketika penggunaan $80 \mathrm{gr}$ ekstrak sekam padi. Hal ini terjadi karena bertambahnya sisi aktif pada partikel zeolit yang menyerap ion logam sehingga semakin banyak pula adsorban yang dapat terjerap pada permukaan partikel zeolit.

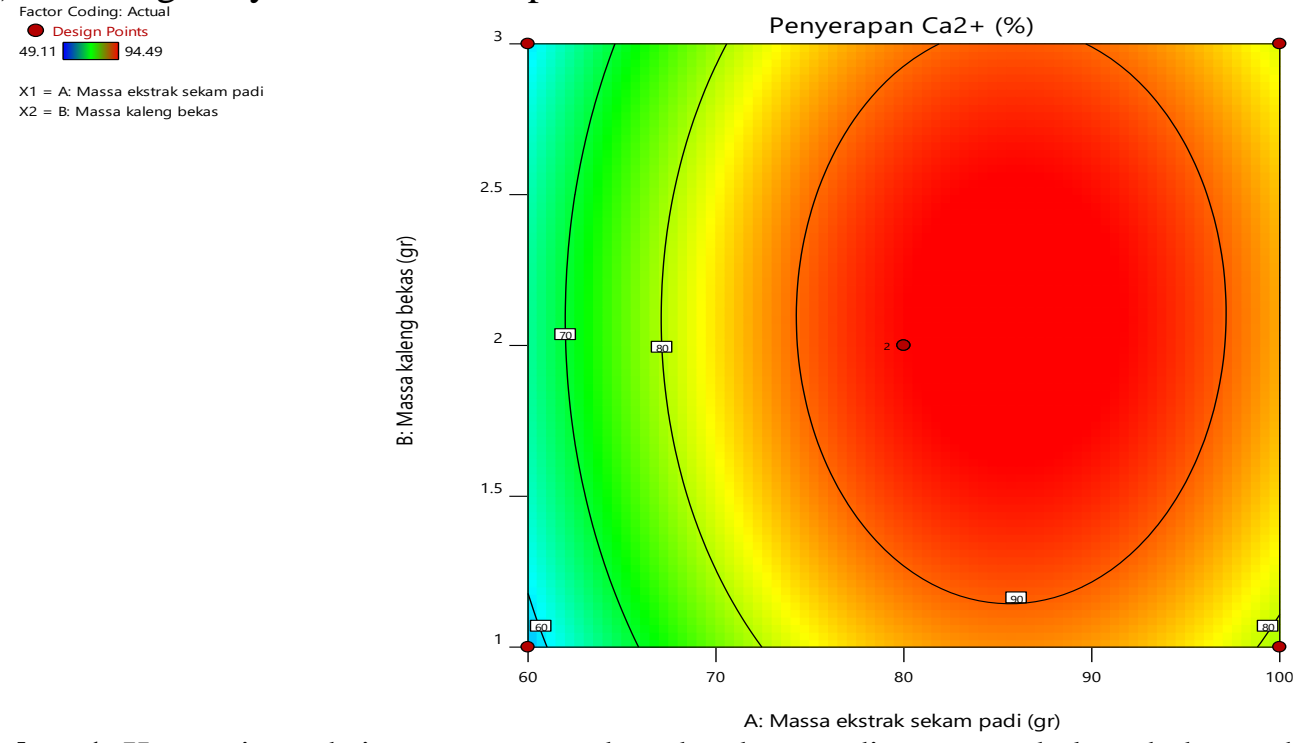

Gambar 1. Kontur interaksi antara massa ekstrak sekam padi vs massa kaleng bekas terhadap penyerapan ion logam $\mathrm{Ca}^{2+}$ 
Factor Coding: Actual

Design Points:

Above Surface

Below Surface

$49.11 \square 94.49$

$\mathrm{X} 1$ = A: Massa ekstrak sekam padi $\mathrm{X} 2=\mathrm{B}$ : Massa kaleng bekas

\section{D Surface}

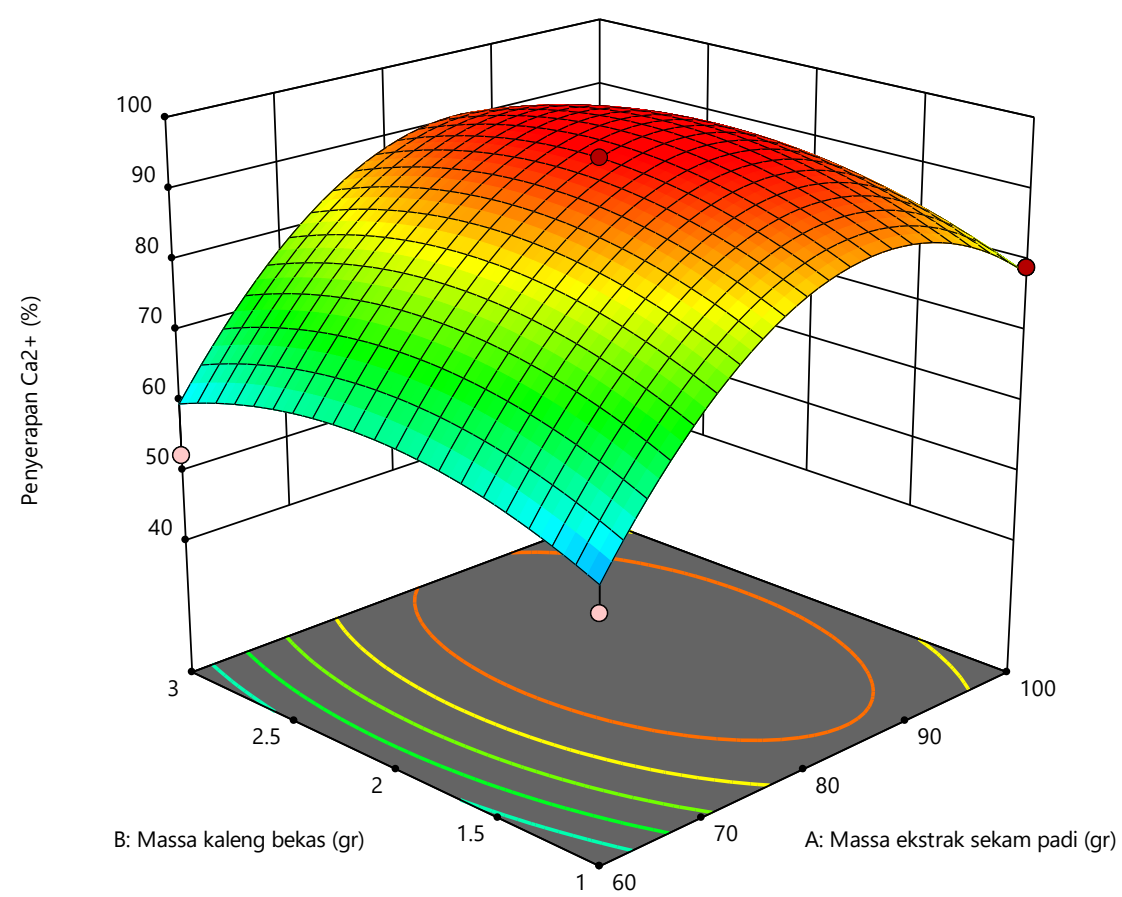

Gambar 2. 3D interaksi antara massa ekstrak sekam padi vs massa kaleng bekas terhadap penyerapan ion logam $\mathrm{Ca}^{2+}$
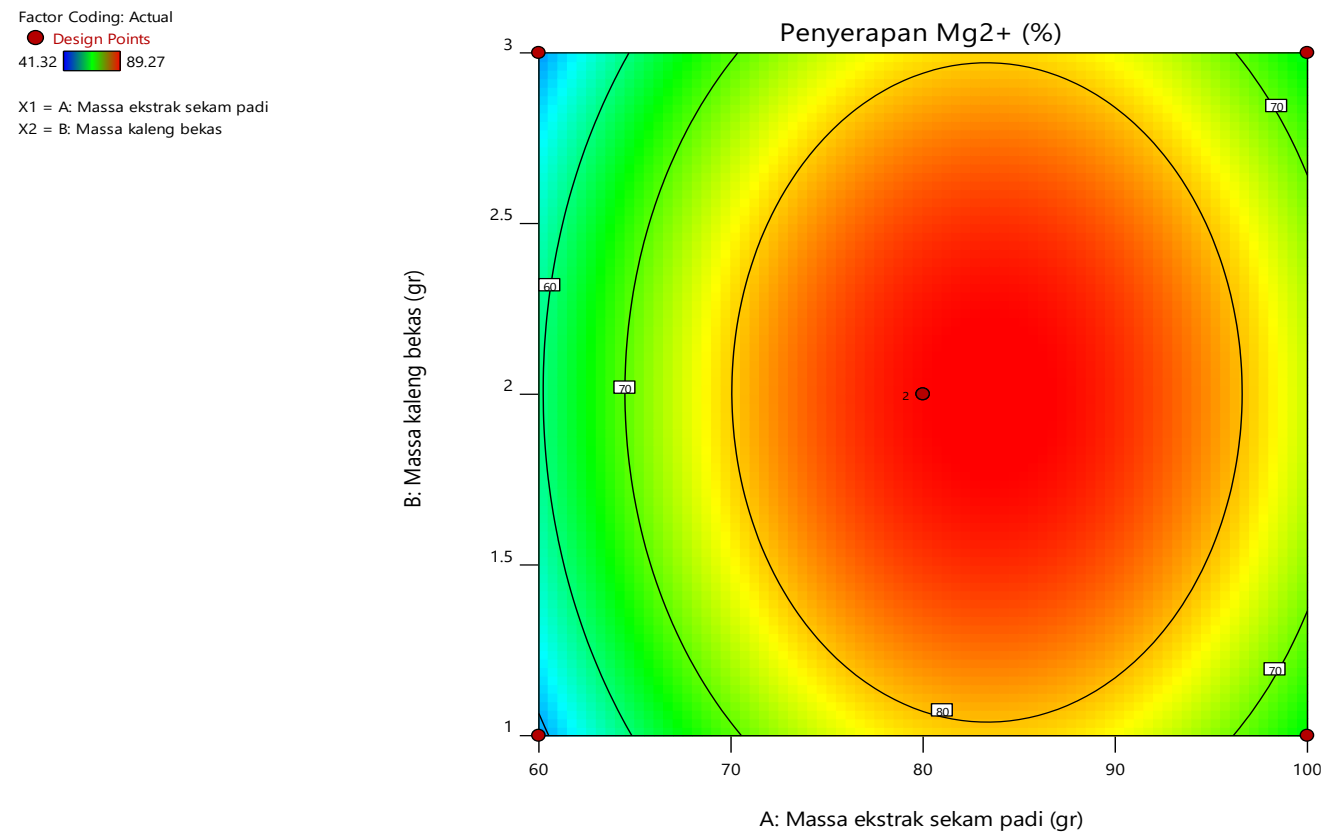

Gambar 3. Kontur interaksi antara massa ekstrak sekam padi vs massa kaleng bekas terhadap penyerapan ion logam $\mathrm{Mg}^{2+}$ 
Factor Coding: Actual Design Points:

Above Surface

Below Surface

$4 1 . 3 2 \longdiv { \square } \square . 2 7$

X1 = A: Massa ekstrak sekam padi $\mathrm{X} 2=\mathrm{B}$ : Massa kaleng bekas

\section{D Surface}

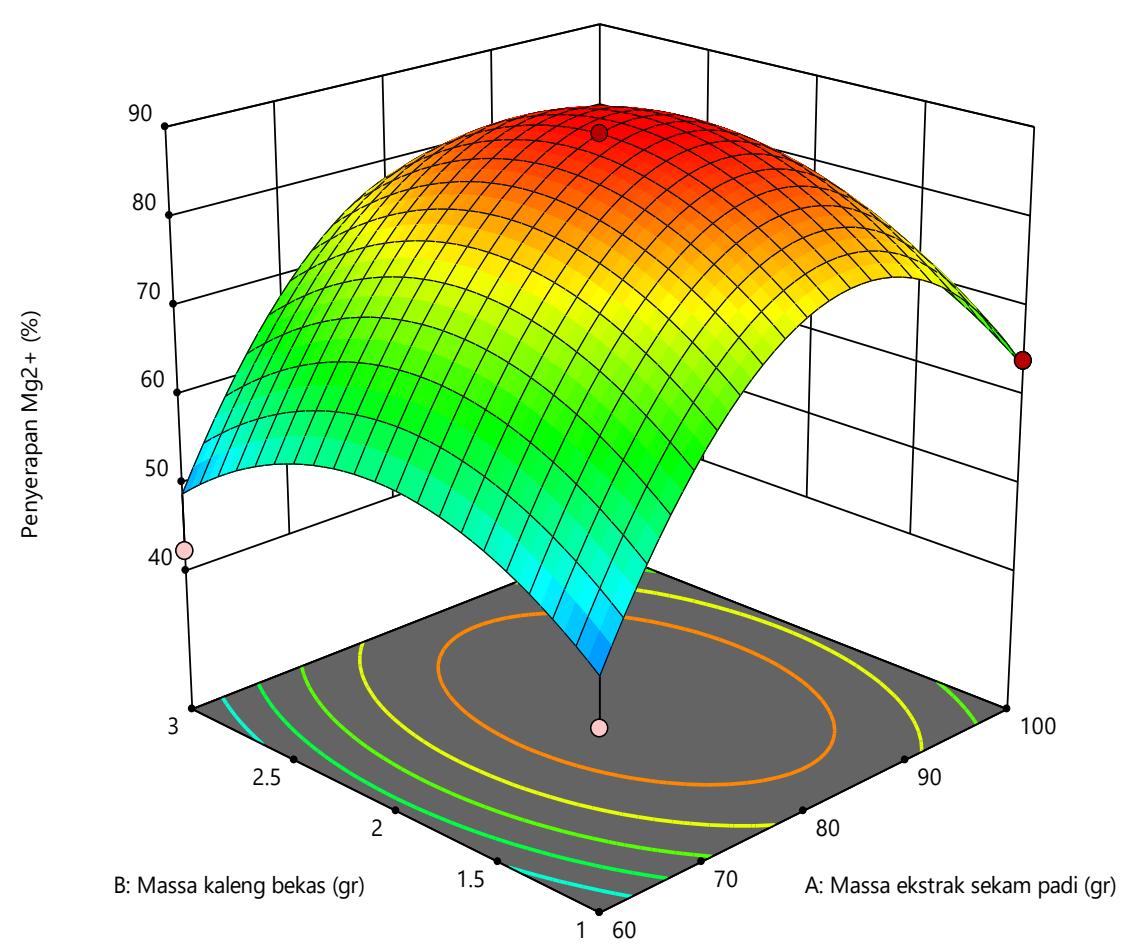

Gambar 4. 3D interaksi antara massa ekstrak sekam padi vs massa kaleng bekas terhadap penyerapan ion logam $\mathrm{Mg}^{2+}$

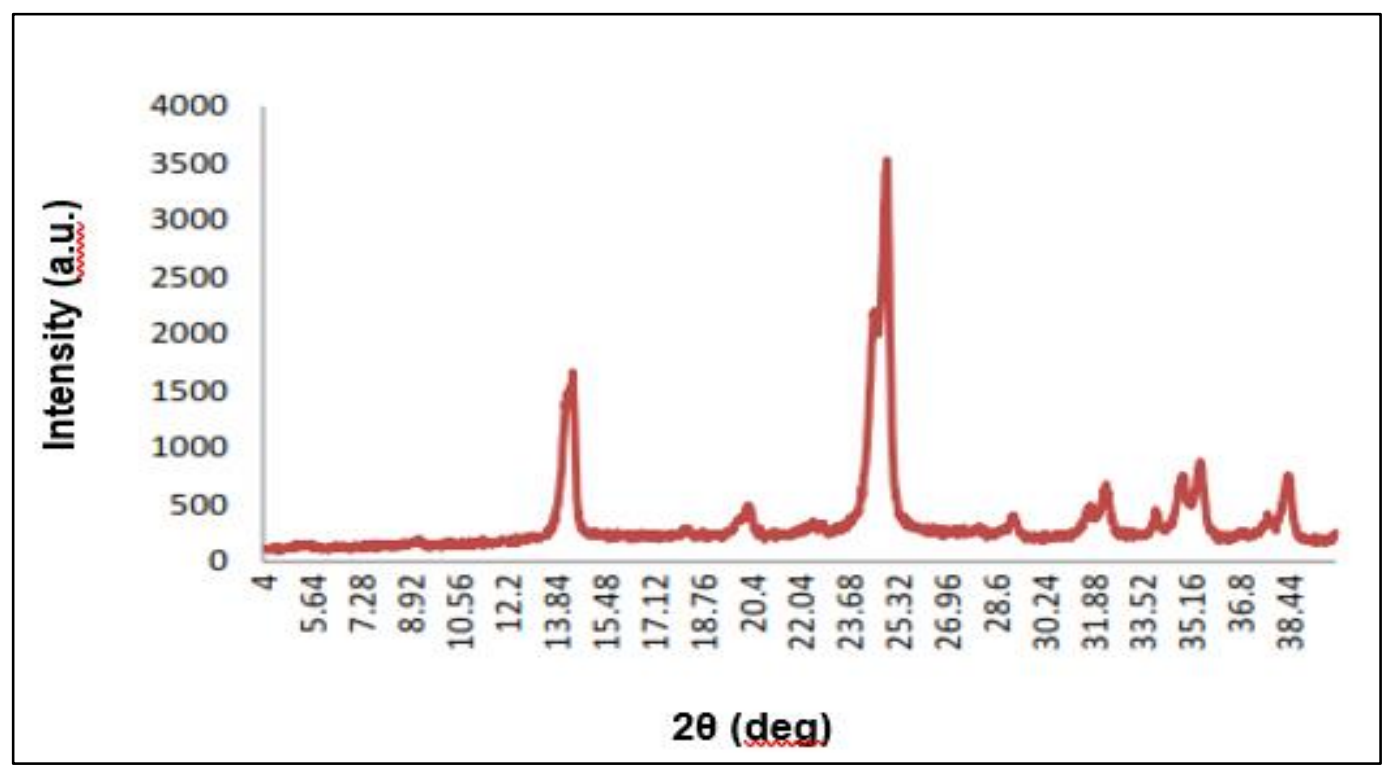

Gambar 5. Difraktogram zeolit

\section{Analisis XRD Zeolit}

Analisis XRD hanya dilakukan pada sampel dengan hasil penyerapan ion logam $\mathrm{Ca}^{2+}$ dan $\mathrm{Mg}^{2+}$ tertinggi saja. Hasil difraktogram zeolit ditunjukkan pada
Gambar 5. Gambar 5 menunjukkan peak atau puncak yang dihasilkan pada $2 \theta: 14.38^{\circ}$ dan $24,94^{\circ}$, yaitu berupa senyawa $\mathrm{SiO}_{2}$. Hal ini sesuai dengan penelitian yang dilakukan Zahara, et al. (2018), dimana peak-peak 
khusus yang muncul dengan intensitas yang tinggi merupakan peak $\mathrm{SiO}_{2}$ berada pada posisi 20: $22-25^{\circ}$ dan posisi $2 \theta$ : $13-15^{\circ}$. Berdasarkan JCPDS nomor 48-1862, zeolit yang dihasilkan merupakan tipe zeolit Y, yaitu tipe zeolit sedang (modernit) dengan kadar Si lebih tinggi dibandingkan kadar Al (rasio Si/Al antara 1-3) (Anggoro, 2017). Sintesis zeolit tersebut menghasilkan zeolit yang lebih baik dibandingkan penelitian. sebelumnya, yaitu sintesis zeolit dari abu sekam padi yang menghasilkan zeolit $\mathrm{A}$ atau zeolit dengan kadar Si rendah (Era, et al., 2016).

\section{KESIMPULAN}

Penyerapan ion logam $\mathrm{Ca}^{2+}$ dan $\mathrm{Mg}^{2+}$ yang optimal pada air sumur dihasilkan pada penggunaan 80 gr ekstrak sekam padi dan 2 gr kaleng bekas sebagai bahan baku pada pembuatan zeolit, yaitu sebesar 94,48\% dan $89,26 \%$. Hal ini disebabkan karena semakin banyak adsorbat yang terjerap pada permukaan partikel zeolit dengan bertambahnya sisi aktif pada partikel zeolit yang menyerap ion logam. Dari hasil difraktogram XRD didapatkan bahwa zeolit yang dihasilkan merupakan tipe zeolit Y.

\section{DAFTAR REFERENSI}

Adans, Y.F., Martins, A.R., Coelho, R.E., Virgens, C. F., Ballarini, A.D., \& Carvalho, L.S. (2016) A Simple Way to Produce $\gamma$-Alumina from Aluminum Cans by Precipitation Reactions. Materials Research, 19 (5), 977-982.

Agung, M.G.F., Hanafie, M.R., \& Mardina, P. (2013). Ekstraksi Silika dari Abu Sekam Padi dengan Pelarut KOH. Konversi, 2 (1): 28-31.

Anggoro, D. D. (2017). Buku Teori dan Aplikasi Rekayasa Zeolit. Semarang: UNDIP Press.
Arviani, W. K. (2019). Tinjauan Kinetika Reaksi Pembuatan Tawas dari Pemanfaatan Aluminium Limbah Kaleng. Skripsi. Surakarta: Universitas Muhammadiyah Surakarta.

Daffalla, S. B., Mukhtar, H., \& Shaharun, M. S. (2012). Effect of Organic and Inorganic Acid Pretreatment on Structural Properties of Rice Husk and Adsorption Mechanism of Phenol. International Journal of Chemistry and Environtment. 3(3), 192-200.

Era, L., Zaharah, T. A., \& Syahbanu, I. (2016). Zeolit Sintesis dari Sekam Padi dan Aplikasinya dalam Menurunkan Kadar Ion Fe (II) pada Air Gambut. Jurnal Kimia dan Kemasan, 5(3): 35-39.

Hasmawati. (2017). Skripsi. Pemanfaatan Tawas Sintetik dari Kaleng Bekas sebagai Koagulan pada Air. Makasar: UIN Alauddin Makasar.

Kristiyani, D., Susatyo, E. B., \& Prasetya, A. T. (2012). Pemanfaatan Zeolit Abu Sekam Padi untuk Menurunkan Kadar Ion $\mathrm{Pb}^{2+}$ pada Air Sumur. Indonesian Journal of Chemistry \& Science, 1(1), 13-19.

Nurhasni, Hendrawati, \& Saniyyah, N. (2010). Penyerapan Ion Logam Cd dan $\mathrm{Cr}$ dalam Air Limbah Menggunakan Sekam Padi. Jurnal Kimia Valensi. 1(6), 310-318.

Silalahi, I. H., Sianipar, A., \& Sayekti, E. (2011). Modifikasi Zeolit Alam Menjadi Material Katalis Perengkah. Jurnal Kimia Mulawarman, 8(2), 8993.

Simanjuntak, W., \& Sembiring, S. (2016). The Use of Liquid Smoke as a Substitute for Nitric Acid for Extraction of Amorphous Silica from 
Rice husk through Sol-Gel Route, Orient. Journal of Chemistry, 39(4), 1 -7 .

Suardana, I. N. (2008). Optimalisasi Daya Adsorpsi Zeolit Terhadap Ion Kromium(III). Jurnal Penelitian danPengembangan Sains \& Humaniora, 2(1), 17-33.

Yang, L., Liu, Z., Liu, Z., Peng, W., Liu, Y., \& Liu, C. (2017). Correlation Between H-ZSM-5 Crystal Size and Catalytic
Performance in The Methanol to Aromatics Reaction. Chinese Journal of Catalyst. 38, 683 - 690.

Zahara, Z., Krisnandi, Y. K., Wibowo, W., Nnurani, D. A., Rahayu, D. U.C., \& Haerudin, H. (2018). Synthesis and Characterization of Hierarchical ZSM-5 Zeolite using Various Templates as Cracking Catalysts. AIP Conference Proceedings. 2023(1), 020088. 